\title{
Conserving a geographically isolated Charaxes butterfly in response to habitat fragmentation and invasive alien plants
}

\begin{tabular}{|c|c|}
\hline \multicolumn{2}{|c|}{$\begin{array}{l}\text { Authors: } \\
\text { Casparus J. Crous }{ }^{1} \\
\text { James S. Pryke }^{1} \\
\text { Michael J. Samways }^{1}\end{array}$} \\
\hline \multicolumn{2}{|c|}{$\begin{array}{l}\text { Affiliations: } \\
{ }^{1} \text { Department of Conservation } \\
\text { Ecology and Entomology, } \\
\text { Stellenbosch University, } \\
\text { South Africa }\end{array}$} \\
\hline \multicolumn{2}{|c|}{$\begin{array}{l}\text { Correspondence to: } \\
\text { Casper Crous }\end{array}$} \\
\hline \multicolumn{2}{|c|}{$\begin{array}{l}\text { Email: } \\
\text { cjcrous@gmail.com }\end{array}$} \\
\hline \multicolumn{2}{|c|}{$\begin{array}{l}\text { Postal address: } \\
\text { Private Bag X1, Matieland } \\
7602 \text {, South Africa }\end{array}$} \\
\hline \multicolumn{2}{|c|}{$\begin{array}{l}\text { Dates: } \\
\text { Received: } 09 \text { Jan. } 2015 \\
\text { Accepted: } 08 \text { July } 2015 \\
\text { Published: } 31 \text { Aug. } 2015\end{array}$} \\
\hline \multicolumn{2}{|c|}{$\begin{array}{l}\text { How to cite this article: } \\
\text { Crous, C.J., Pryke, J.S. \& } \\
\text { Samways, M.J., 2015, } \\
\text { 'Conserving a geographically } \\
\text { isolated Charaxes butterfly } \\
\text { in response to habitat } \\
\text { fragmentation and invasive } \\
\text { alien plants', Koedoe 57(1), } \\
\text { Art. \#1297, } 9 \text { pages. http:// } \\
\text { dx.doi.org/10.4102/koedoe. } \\
\text { v57i1.1297 }\end{array}$} \\
\hline \multicolumn{2}{|c|}{$\begin{array}{l}\text { Copyright: } \\
\text { (C) 2015. The Authors. } \\
\text { Licensee: AOSIS } \\
\text { OpenJournals. This work is } \\
\text { licensed under the Creative } \\
\text { Commons Attribution } \\
\text { License. }\end{array}$} \\
\hline \multicolumn{2}{|l|}{ Read online: } \\
\hline 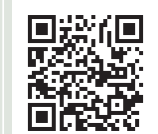 & $\begin{array}{l}\text { Scan this QR } \\
\text { code with your } \\
\text { smart phone or } \\
\text { mobile device } \\
\text { to read online. }\end{array}$ \\
\hline
\end{tabular}

In South Africa, much of the forest biome is vulnerable to human-induced disturbance. The forest-dwelling butterfly Charaxes xiphares occidentalis is naturally confined to a small forest region in the south-western Cape, South Africa. Most of the remaining habitat of this species is within a fragmented agricultural matrix. Furthermore, this geographical area is also heavily invaded by alien plants, especially Acacia mearnsii. We investigated how $C$. $x$. occidentalis behaviourally responds to different habitat conditions in the landscape. We were particularly interested in touring, patrolling and settling behaviour as a conservation proxy for preference of a certain habitat configuration in this agricultural matrix. Remnant forest patches in the agricultural matrix showed fewer behavioural incidents than in a reference protected area. Moreover, dense stands of $A$. mearnsii negatively influenced the incidence and settling pattern of this butterfly across the landscape, with fewer tree settlings associated with more heavily invaded forest patches. This settling pattern was predominantly seen in female butterflies. We also identified specific trees that were settled upon for longer periods by C. $x$. occidentalis. Distance to a neighbouring patch and patch size influenced behavioural incidences, suggesting that further patch degradation and isolation could be detrimental to this butterfly.

Conservation implications: We highlight the importance of clearing invasive tree species from vulnerable forest ecosystems and identify key tree species to consider in habitat conservation and rehabilitation programmes for this butterfly. We also suggest retaining as much intact natural forest as possible. This information should be integrated in local biodiversity management plans.

\section{Introduction}

In South Africa, the forest biome is the smallest of all biomes $(<1 \%$ surface cover) and is highly sensitive to environmental disturbances (Eeley, Lawes \& Piper 1999). As many people continue to rely on native forests for their livelihoods, this biome is one of the most vulnerable and threatened vegetation types in the country (Shackleton et al. 2007). In these forests is a charismatic butterfly species: the forest king emperor (Nymphalidae: Charaxinae: Charaxes xiphares), a large and fast-flying butterfly. Moreover, this species has nine subspecies, all of which are geographically distinct (Woodhall 2005). Unfortunately, fruit-feeding butterflies are often highly sensitive to forest disturbance (Fermon et al. 2000; Uehara-Prado, Brown \& Freitas 2007). Little information is available on forest-dwelling butterfly ecology in the threatened South African forest biome.

The south-western Cape region of South Africa has many small natural forest patches that today are mainly within a cultivated agricultural landscape. Many of these forest patches have been reduced in size to provide pasture and fodder for cows. As a result, few of the forest patches remain intact, especially with regard to their original size. Within this region lies an important protected area, namely the Grootvadersbosch Nature Reserve. Here, the subspecies C. $x$. occidentalis Pringle is endemic. This is the most southern subspecies of C. xiphares (Woodhall 2005). This protected area and many of the fragmented forest patches are situated in mainly a dairy farming matrix. These farms are part of the Grootvadersbosch Conservancy, although there is no conservation plan (other than the formally protected area) to protect the habitat of this highly localised butterfly population.

Many of the remnant forest patches in the Grootvadersbosch Conservancy are along rivers and streams, which bring them into contact with invasive alien plant species, another threat to the biodiversity in this landscape (Hood \& Naiman 2000). South African river systems are particularly threatened, with less than a third of the main rivers currently ecologically intact (Nel et al. 2007). These riverbanks are heavily invaded by the alien tree Acacia mearnsii De Wild 
(Fabaceae). Acacia mearnsii trees often form homogenous stands within catchment areas, which severely alter stream hydraulic characteristics across the landscape, and ultimately negatively affect plant community structure and biodiversity in the catchment area (Dye \& Jarmain 2004; Enright 2000; Le Maitre et al. 2002, 2011).

Biotic homogenisation is strongly associated with anthropogenic mass extinction events (McKinney \& Lockwood 1999). Production landscapes are particularly prone to these events, as biodiversity reductions associated with such landscapes often increase the invasion potential of alien species (Fargione \& Tilman 2005). Therefore, managing forest-dwelling butterflies effectively in a forestagricultural matrix will require a deeper understanding of the role that natural environmental heterogeneity plays in butterfly dispersal patterns (Hamer et al. 2003). For example, preserving heterogeneity in native tree canopy structure and prohibiting invasive tree species from forming dense stands within native forests are important for conserving fruit-feeding butterflies (Hamer et al. 2003). Indeed, many butterflies are sensitive to changes in habitat conditions due to alien plant invasions (Edge 2005; Florens et al. 2010; Hanula \& Horn 2011; Lawrence \& Samways 2002; Lu \& Samways 2002; but see Graves \& Shapiro 2003). As invasive Acacia trees in South Africa severely degrade the local plant community structure (Le Maitre et al. 2011), which could include reducing the presence or density of the butterfly's larval and adult feeding plants, the effect of $A$. mearnsii on the dispersal of C. $x$. occidentalis in this increasingly fragmented landscape requires understanding. The relevance of this information is underscored by there being no evidence that the larvae or adults of this Charaxes subspecies utilise Fabaceae plants as a habitat resource.

As there is currently no research on the response of $C . x$. occidentalis to disturbed Southern Afrotemperate Forest, it is essential to identify the landscape variables that can contribute to this butterfly's conservation in this production landscape. Behavioural studies can be particularly useful to identify these preferences (New 1991; Shreeve 1984; Thomas 1984). Behavioural studies can reveal specific habitat requirements needed for a species or community, and subsequently how to optimally conserve their habitat or biotope (Crous, Samways \& Pryke 2014; Sutherland 1998; Turlure et al. 2011). Understanding how different resource conditions influence butterfly behaviour is crucial for understanding their distribution patterns across space and time (Shreeve \& Dennis 2011).

In this study we use behavioural observations to determine the response of $C$. $x$. occidentalis to remnant patches of Southern Afrotemperate Forest embedded in a dairy farming matrix. Furthermore, we examine the effect that A. mearnsii invasion has on aspects of the butterfly's behaviour. Our key questions related to effective conservation are therefore two tiered. At one level, we aim to determine (1) the activity (number of behavioural incidences) of adults of C. $x$. occidentalis in remaining forest fragments with different invasion levels, (2) the activity of adults of this species in the protected area vis-à-vis in the forest fragments and (3) which environmental variables may help explain the different behavioural activities across the landscape. At the second level, we aim to establish (1) whether there is a consistent native tree community upon which the adult butterfly population shows a positive settling response (with settling as a conservation proxy for preference) and (2) which tree species are especially important to this butterfly within the fragmented forest fragments.

\section{Research method and design}

\section{Study area}

We recorded the behaviour of $C$. $x$. occidentalis at 11 sites in the Grootvadersbosch Conservancy and the Grootvadersbosch Nature Reserve (the latter abbreviated here to PA for 'protected area' to distinguish this reference site from the forest fragments in the conservancy), Western Cape, South Africa (Figure 1). The $2.5-\mathrm{km}^{2} \mathrm{PA}$ is considered the secondlargest patch of Southern Afrotemperate Forest, preceded only by the considerably larger Knysna-Tsitsikamma forest (narrow coastal strip of $250 \mathrm{~km}$ ), about $100 \mathrm{~km}$ east of this PA. The Langeberg mountain range runs north of both the closest town and the PA. The geology of the Langeberg mountain range is mostly Table Mountain Sandstone and forms part of the greater Cape Fold Belt. Patches of Southern Afrotemperate Forest occupy the wetter southern slopes of this mountain range. This forest vegetation type occurs at elevations between $10 \mathrm{~m}$ a.s.l. near its coastal distribution range and 1060 ma.s.l. at thehighest measured peak(Mucina \& Rutherford 2006). All sites were situated on the southfacing lower slopes of this mountain range. The elevation range of the study sites was $115 \mathrm{~m}$ a.s.l. - $324 \mathrm{~m}$ a.s.l., with an average elevation of $190 \mathrm{~m}$ a.s.l. The Grootvadersbosch region lies in the transitional zone between the winter and all-year rainfall regions, with up to $1050 \mathrm{~mm}$ of mean annual precipitation recorded for the PA. The existing remnant Afrotemperate forest patches within the dairy farming matrix of the conservancy are mostly restricted to rivers or streams.

\section{Design}

We selected 11 sites along four river systems that flow through the catchment area (Figure 1). The Duivenhoks River, which is a small stream that also flows through the PA (not indicated on the map), flows towards the southeast. One site (PA1) was along this river. We focus on forest along these rivers because of the remnant patches here still being intact. As so little is known about the presence of the butterfly across this fragmented landscape, we also focused, as a theoretical starting point, on forest patches where at least Scutia myrtina, the larval food plant of C. $x$. occidentalis, was present (Woodhall 2005).

Of the 11 selected sites, two were along streams in the 250-ha patch of continuous forest that constitutes the PA (sites were $2398 \mathrm{~m}$ apart). Six sites were remnant forest 


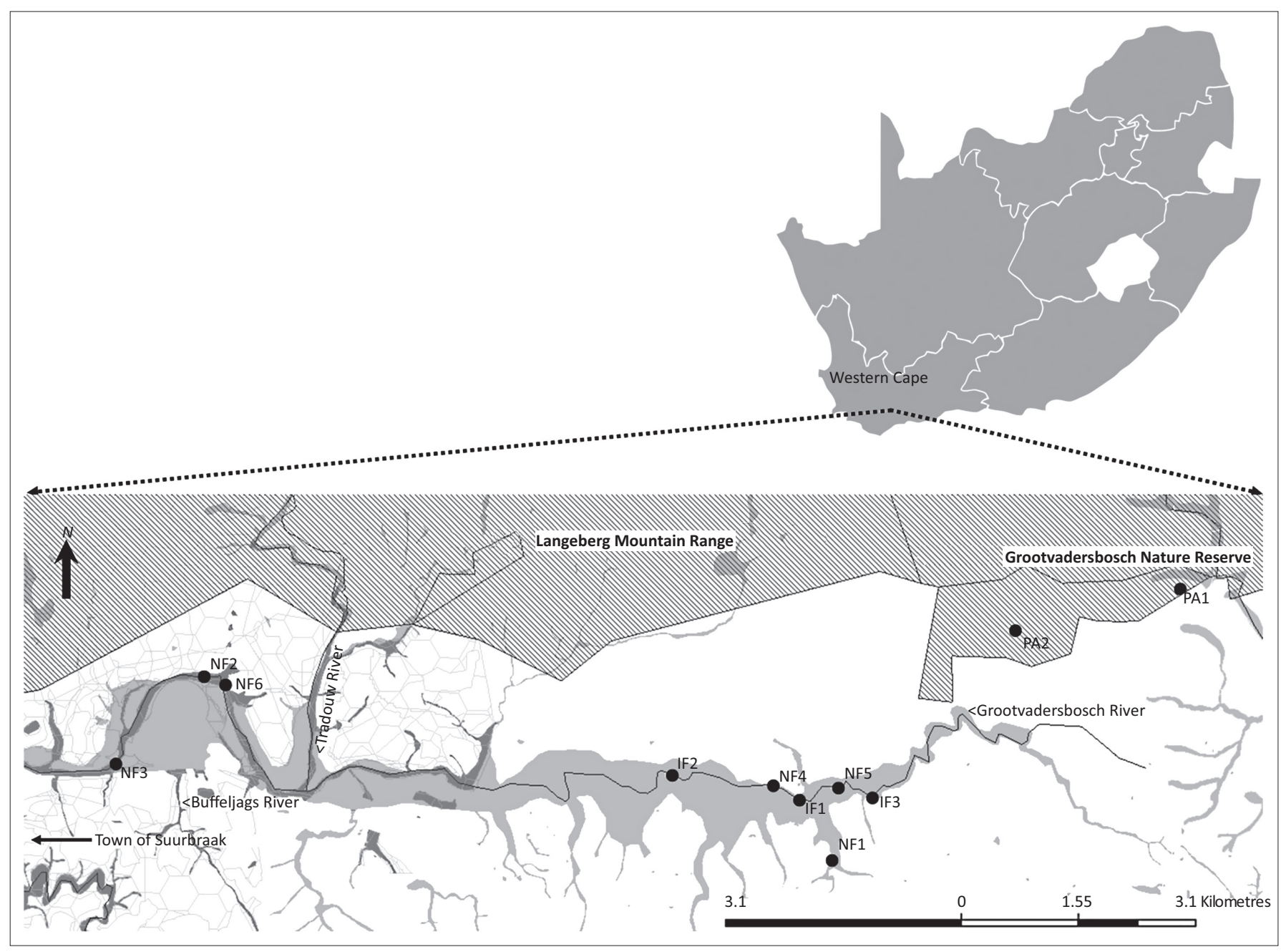

Note: The cross-hatched areas are formally protected. The two study sites indicated in this area are part of the Grootvadersbosch Nature Reserve managed by CapeNature. All the other study sites are discontinuous patches along rivers or streams within a dairy farming matrix.

FIGURE 1: Location of study sites within the Grootvadersbosch Conservancy, near the town of Suurbraak in the Western Cape province, South Africa.

patches in the conservancy of the agricultural matrix (natural fragments; NF), which we classified as patches that showed little or no indication of disturbance, either morphologically (riverbank structure) or biologically (alien plant species). These sites were between $319 \mathrm{~m}$ and 9182 m apart. Lastly, we selected three remnant forest patches invaded by $A$. mearnsii, also in the conservancy agricultural matrix and interspersed with the natural fragments (invaded fragments; IF). The riverbanks here were degraded morphologically. Specifically, an invaded site was where $>75 \%$ of the trees were A. mearnsii (homogenous stands). The latter sites were between $1031 \mathrm{~m}$ and $2829 \mathrm{~m}$ apart. The variable number of studied sites in each of the mentioned categories was a factor of the availability of similar sites across this small region (a discontinuous forest-agriculture matrix; see Uehara-Prado et al. 2007). For example, the IFs were not consistent across the area owing to some land users actively weeding invasive alien plants whereas others do not. This also means that the sizes of the studied remnant forest fragments differed. However, to standardise the sampling in this case, we surveyed and compared a fixed forest fragment area where at least the butterfly's larval food plant was present.

\section{Procedure}

\section{Behavioural observations}

Behaviour of both sexes of the butterfly was observed at each of the 11 sites by the same two observers in January 2014. The study period was during the peak flying season of this butterfly. Observation took place between 10:00 and 14:00 on warm or hot days with $<10 \%$ cloud cover (average temperature: $30.4{ }^{\circ} \mathrm{C} \pm 2.6 \mathrm{SD}$ ). Eight hours of total observation time were spent per site. Behaviour recording started as soon as a C. $x$. occidentalis individual entered a circle of a $10-\mathrm{m}$ radius and ended when the butterfly left the circle. A $10-\mathrm{m}$ radius was used for each observer to observe at least a 20-m strip of forest trees in the remaining habitat. As proxies for the response of this butterfly to its immediate environment, only the following behavioural observations were recorded:

- patrolling - the individual flies low over the area at low speed, as if investigating or searching

- touring - the individual flies high over the area and at high speed, without showing any searching or investigating behaviour

- settling - the individual is settled on an object; settling may integrate other behaviours, such as resting, basking, feeding or ovipositing. 
The amount of time an individual exercised a particular behaviour was also recorded.

\section{Landscape variables}

We chose four landscape variables for correlation with the behavioural observations:

- tree species richness in the sampled belt

- size of the patch of native forest in which the sampling belts occurred

- distance of the fragments to the PA

- distance of the fragments to the nearest large protected patch on a land-user property.

The latter variable refers to a group of isolated forest patches on a farm, extending more inland or up the mountain as opposed to patches mainly being riparian, and ultimately present owing to ongoing tree protection efforts by the land user (non-nature reserve or informal protection; in this case an approximately 20-ha patch). For this variable, the PA could also be considered a protected patch on a large landuser property in this landscape.

Prior to butterfly sampling, tree species richness of each fragment (identified to at least genus level) was estimated by two trained observers using a $50-\mathrm{m} \times 10-\mathrm{m}$ belt $(50 \mathrm{~m}$ parallel to the river-facing forest edge and $<10 \mathrm{~m}$ into the forest). At NF5, however, the forest did not always extend past $10 \mathrm{~m}$ owing to uneven fragmentation (ranging between $8 \mathrm{~m}$ and $15 \mathrm{~m}$ ). We used the $10-\mathrm{m}$ cut-off perpendicular to the stream to complement the $10-\mathrm{m}$ radius of the butterfly sampling circle. This variable was chosen to determine whether decreasing tree richness in the fragments has an effect on the butterfly activity in the area. Tree identifications were in random directions (non-linear searches) within each sampled belt, and it took up to an hour to identify all species. The distance of each forest patch to the PA and the two largest and actively conserved forest patches was calculated from images from Google Earth (Google, Inc., Mountain View, USA).

\section{Analyses}

Statistical analysis software (Statistica Version 12, StatSoft, Tulsa, USA) was used for initial statistical analyses. To observe the number of behavioural incidences recorded between the PA and the NFs and IFs (non-nature reserve sites), a bar graph was constructed showing standard deviations. To compare the mean number of behavioural incidences recorded in each behavioural category across these non-nature reserve sites, we used one-way analyses of variance. A Shapiro-Wilk test showed that values in each category were normally distributed and their variances were homogenous. However, quantile-quantile plots suggested that a non-parametric analysis would be more appropriate for the touring category. Non-parametric Mann-Whitney $U$ tests were performed to establish whether there were sexspecific responses in each behavioural class across the NFs and IFs. This test was performed as male settling, female settling and female touring behaviour values were not normally distributed.

A Spearman non-parametric rank correlation matrix was constructed to determine the possible relationship between the total number of behavioural incidences observed for each behavioural trait and the four measured environmental variables. This test was chosen because some of the environmental variables were not normally distributed.

In addition to behavioural incidence patterns, we also determined which community of trees $C$. $x$. occidentalis spent the most time settling upon, and whether this was consistent across sites, using a non-metric multidimensional scaling (NMDS) ordination in PRIMER 6 (PRIMER-E, Lutton, UK). NMDS is a non-linear, distance-based technique that ranks different samples or groups in ordination space according to their similarity/dissimilarity (Ter Braak 1995). For this particular NMDS, we used time (seconds) as a measure of the 'abundance' of the time individual butterflies spent on different trees within a site. We excluded S. myrtina (the known larval food plant) from this analysis. This ensured that we focused on trees used by C. $x$. occidentalis for reasons other than ovipositing. A Bray-Curtis similarity matrix (which takes into account abundance) was used and data were fourth-root transformed. NMDS therefore indicated the butterfly's tree community settling pattern (TCSP) across the study area. Furthermore, to determine which tree species strongly structured differential tree community settling (i.e. were settled upon for longer periods), we vectored (correlated) those tree species with Pearson correlations $(r)$ $>0.8$ onto the NMDS axes in PRIMER 6. We specifically chose the strongest possible correlation to ensure that we identify the tree species that most strongly influences the variation in settling behaviour of this butterfly amongst the studied sites.

To test for possible spatial autocorrelation between tree use activity patterns and distance between sites (i.e whether closer sites are more alike in tree activity use), we used the RELATE function in PRIMER 6. This is a Mantel-type test that correlates two similarity matrices with each other. To obtain the between-site distance matrix, we used the Geographic Distance Matrix Generator v.1.2.3 (Ersts n.d.). For this RELATE test, we used Spearman's rho with 9999 permutations.

\section{Results}

The highest number of behavioural incidences recorded was in the PA (Figure 2). In total, and for each behavioural category, there was a general, stepwise decrease in the number of behavioural incidences recorded when scaling from the PA to the IFs (Figure 2). The more intact forest patches also had the highest number of individuals entering a sampling circle, of which most were female (Table 1). Specifically, the more intact fragments had generally more behavioural incidences than the invaded fragments $(F=5.18, P=0.057)$. This trend was mainly due to the significantly higher settling behaviour in the NFs than in the IFs $(F=7.98, P=0.026$; Table 2$)$. 


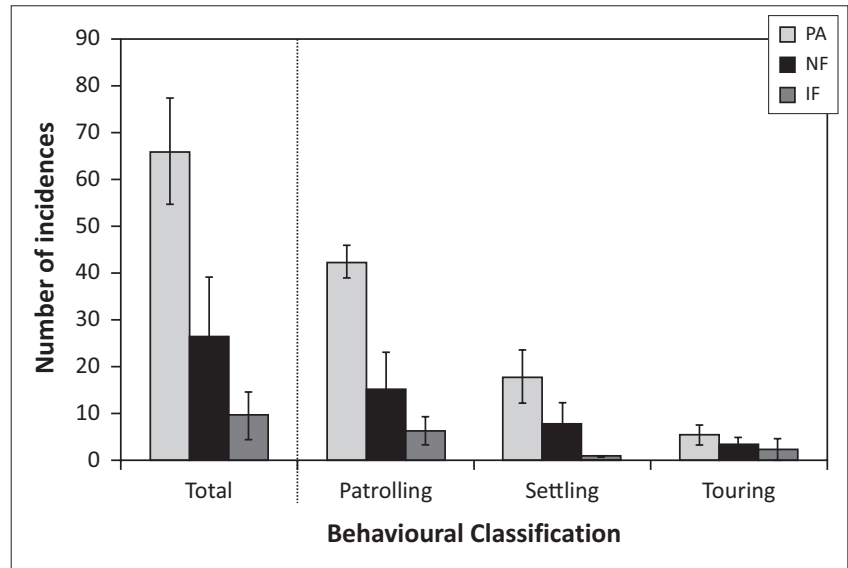

IF, invaded forest fragments; NF, natural forest; PA, protected area (Grootvadersbosch Nature Reserve)

FIGURE 2: Means $( \pm S D)$ of total observed butterfly behavioural incidences, as well as the incidences in each behavioural classification, in the Grootvadersbosch Nature Reserve forest $(n=2)$, the natural forest fragments $(n=6)$ and the forest fragments invaded by Acacia mearnsii $(n=3)$.

TABLE 1: The average number of Charaxes xiphares occidentalis individuals that entered a sampling radius (as a proxy for abundance) from which behavioural data were recorded, as well as their sexual delineation.

\begin{tabular}{|c|c|c|c|c|c|}
\hline \multirow[t]{2}{*}{ Sampling site } & \multirow[t]{2}{*}{$n$} & \multicolumn{2}{|c|}{$\begin{array}{c}\text { Average number } \\
\text { of butterflies }\end{array}$} & \multirow[t]{2}{*}{$\begin{array}{c}\text { Male } \\
\text { butterflies (\%) }\end{array}$} & \multirow[t]{2}{*}{$\begin{array}{c}\text { Female } \\
\text { butterflies (\%) }\end{array}$} \\
\hline & & Mean & $\pm 1 \mathrm{SE}$ & & \\
\hline Protected area & 2 & 31.50 & 1.5 & 35 & 65 \\
\hline Natural fragments & 6 & 13.17 & 2.9 & 27 & 73 \\
\hline Invaded fragments & 3 & 6.67 & 3.3 & 51 & 49 \\
\hline
\end{tabular}

$n$, number; SE, standard error.

TABLE 2: Results of one-way analyses of variance and a Mann-Whitney $U$ test to compare the number of incidences in all and within each studied butterfly behavioural classification across natural and invaded forest patches in a dairy farming matrix.

\begin{tabular}{lcccccc}
\hline Behavioural class & $\boldsymbol{d} \boldsymbol{f} \boldsymbol{i}$ & MS & $\boldsymbol{F}$-value & $\boldsymbol{P}$-value & $\boldsymbol{U}$-value & $\boldsymbol{Z}$-score \\
\hline All & 1 & 580.04 & 5.19 & 0.057 & - & - \\
Settling & 1 & 98.00 & 7.98 & $\mathbf{0 . 0 2 6}$ & - & - \\
Patrolling & 1 & 156.06 & 3.28 & 0.113 & - & - \\
Touring & - & - & - & 0.439 & 6.00 & 0.77
\end{tabular}

Note: Natural fragments $(n=6)$; invaded fragments $(n=3)$

$d f$, degrees of freedom; MS, mean square.

$\dagger$, Error degrees of freedom $=7$.

TABLE 3: Results of Mann-Whitney $U$ tests of sex-specific behavioural incidences within each studied behavioural classification in natural and invaded forest patches in a dairy farming matrix.

\begin{tabular}{llccccc}
\hline Sex & $\begin{array}{l}\text { Behavioural } \\
\text { class }\end{array}$ & $\begin{array}{c}\text { Rank } \\
\text { sum NF }\end{array}$ & $\begin{array}{c}\text { Rank } \\
\text { sum IF }\end{array}$ & $\boldsymbol{U}$-value & $\boldsymbol{Z}$-score & $\boldsymbol{P}$-values \\
\hline Male & Patrolling & 27.5 & 17.50 & 6.50 & -0.54 & 0.586 \\
butterflies & Touring & 31.5 & 13.50 & 7.50 & 0.26 & 0.793 \\
& Settling & 28.5 & 16.50 & 7.50 & -0.36 & 0.722 \\
Females & Patrolling & 37.0 & 8.00 & 2.00 & 1.69 & 0.091 \\
butterflies & Touring & 33.5 & 11.50 & 5.50 & 0.86 & 0.391 \\
& Settling & 39.0 & 6.00 & 0.00 & 2.21 & $\mathbf{0 . 0 2 7}$ \\
\hline
\end{tabular}

Note: $\mathrm{NF}=6 ; \mathrm{IF}=3$

$\mathrm{NF}$, natural fragments; IF, fragments invaded by Acacia mearnsii.

Notably, this overall higher settling behaviour in the NFs was specifically a function of female settling behaviour ( $Z=2.21, P=0.027$; Table 3$)$. Neither touring behaviour nor patrolling behaviour differed significantly between natural and invaded patches (Table 2).

Settling incidences (as a conservation proxy for resource preference in a site) and patrolling incidences were both positively correlated with tree species richness $\left(r_{s}=0.90\right.$ and $r_{s}=0.75$, respectively) and patch size $\left(r_{s}=0.92\right.$ and $r_{s}=0.75$, respectively). However, settling and patrolling incidences were negatively correlated with distance to a large protected forest patch at a land user in the landscape $\left(r_{s}=-0.71\right.$ and $r_{s}=-0.67$, respectively) $(n=11$; Table 4$)$. In turn, touring behaviour was significantly correlated only with patrolling $\left(n=11 ; r_{s}=0.62\right.$; Table 4$)$. Patch size was positively correlated with tree species richness $\left(r_{s}=0.86\right)$ and the amount of time an individual butterfly settled in the patch $\left(r_{s}=0.62\right.$; Table 4$)$.

There was no spatial autocorrelation between the TCSP of C. $x$. occidentalis and the distances between sites $\left(r_{s}=-0.054\right.$, $P=0.596)$. This suggests that in situ patch conditions in this particular landscape are more important for determining longer settling behaviour than the proximity of sites to one another. Furthermore, there was a strong tendency for different tree selection by individual butterflies under certain site conditions (NMDS, 2D Stress 0.05; Figure 3). In particular, the two PA sites grouped together, with Olea capensis and Canthium inerme being the tree species that were most strongly correlated with driving TCSP. Notably, two NFs and an IF also had a more similar adult TCSP. Here, the settling time of C. $x$. occidentalis on Buddleja saligna structured this site grouping (Figure 3). Across all sites, the most consistent settling behaviour was on S. myrtina (Table 5), the butterfly's larval food plant that was present in all studied sites. This confirms the importance of this species for conservation. There was only one incident of a male individual settling on an A. mearnsii tree (for $2 \mathrm{~min}$ ) during the entire sampling period (Table 5).

\section{Discussion}

\section{The presence of Charaxes xiphares occidentalis across this fragmented landscape}

It was encouraging to see that this butterfly species was recorded in all the remnant patches here, despite invasion by $A$. mearnsii. However, it was clear that the number of individuals entering a sampling radius and the total recorded behavioural incidences were fewer in fragments invaded by $A$. mearnsii. This was especially evident when directly comparing the invaded sites with the intact and formally protected sites, where $>3$ times the number of behavioural incidences were observed. There were also more behavioural incidences in the PA sites than in the natural remnants. So, although C. $x$. occidentalis was present at all sites, it was more active at the more physically and biologically intact sites. This variance in activity patterns can be attributed to the tree settling incidences, recorded here as an indication of resource preference in their immediate habitat, and which were significantly higher in the NFs than the IFs. This result supports findings from further north in the country, where dense stands of $A$. mearnsii negatively affected the behaviour of butterflies, with individuals mostly touring over invaded areas (Lawrence \& Samways 2002). These results are also consistent with a study on lupine-invaded areas in Finland, where higher alien plant cover resulted in more fly-over 
TABLE 4: A rank correlation matrix of Spearman rank correlations $(r)$ to compare the relationships between measured environmental variables and behavioural traits across all sites $(n=11)$.

\begin{tabular}{|c|c|c|c|c|c|c|c|c|}
\hline Variables & Settling & Patrolling & Touring & Time settled & Tree SR & Dist PA & Dist LP & PSize \\
\hline Settling & - & 0.92 & 0.47 & 0.56 & 0.90 & -0.15 & -0.71 & 0.92 \\
\hline Patrolling & - & - & 0.62 & 0.51 & 0.75 & -0.16 & -0.67 & 0.75 \\
\hline Touring & - & - & - & -0.04 & 0.17 & -0.25 & -0.30 & 0.19 \\
\hline Time settled & - & - & - & - & 0.54 & -0.16 & -0.46 & 0.62 \\
\hline Tree SR & - & - & - & - & - & 0.10 & -0.79 & 0.86 \\
\hline Dist PA & - & - & - & - & - & - & 0.25 & -0.25 \\
\hline Dist LP & - & - & - & - & - & - & - & -0.63 \\
\hline
\end{tabular}

Note: Bold values indicate statistical significance at the $5 \%$ level $(p<0.05)$.

Tree SR, tree species richness; Dist PA, distance to protected area; Dist LP, distance to large protected patch; PSize, patch size.

(touring) behaviour amongst butterfly individuals, resulting in fewer settling and feeding events (Valtonen, Jantunen \& Saarinen 2006). However, the overall higher settling response in NFs observed in this study was primarily a femaledriven pattern. Thus, the fragmented nature of the remnant patches, aggravated by the specific presence of dense stands of A. mearnsii trees, is particularly negative towards habitat suitability for female individuals of C. x. occidentalis.

The mechanism as to how and why A. mearnsii trees negatively affected the behaviour of female $C . x$. occidentalis is related to the strong positive correlation between native tree species richness, size of the remnant patch and activity incidences. It is likely that more female C. $x$. occidentalis individuals patrol the larger intact forest patches with higher native tree species richness and subsequently settle on a tree. In South African riparian areas, A. mearnsii often forms dense stands. This essentially almost homogenises riverbanks, with the consequence of decreased biodiversity (Dye \& Jarmain 2004; Enright 2000; Le Maitre et al. 2002). As the presence of the host plant, as well as its density, will affect female butterfly behaviour in the landscape (Rutowski 1991), the current (and expanding) dense stands of A. mearnsii trees in this catchment will inevitably curb host plant presence and density. Furthermore, alien plants may reduce the presence of certain specialist canopy-dwelling butterfly species (Ghazoul 2004). Homogenisation of gallery forest canopy structure in the remaining natural patches may therefore also be a major contributor to C. $x$. occidentalis settling less often in such environments, as heterogeneity in the tree canopy cover is often critical for maintaining butterfly species in an area (Francesconi et al. 2013; Koh \& Sodhi 2004). Essentially, certain forest fragments, and especially those heavily invaded by A. mearnsii trees, seem to create matrix resistance (Ricketts 2001) regarding the settling (resource use) activity of female C. $x$. occidentalis. As there was only one incidence of a male individual settling on an A. mearnsii tree, it means, theoretically, that the resource base of suitable forest habitat for this butterfly is declining in this agricultural landscape. We therefore support the view on the conservation importance of understanding the role of biotope structure and its changes for shaping butterfly movement across space and time (Dover \& Settele 2009).

Notably, distance of sites to the extensive and intact PA (Grootvadersbosch Nature Reserve) was not correlated with higher behavioural incidences in C. $x$. occidentalis. However,

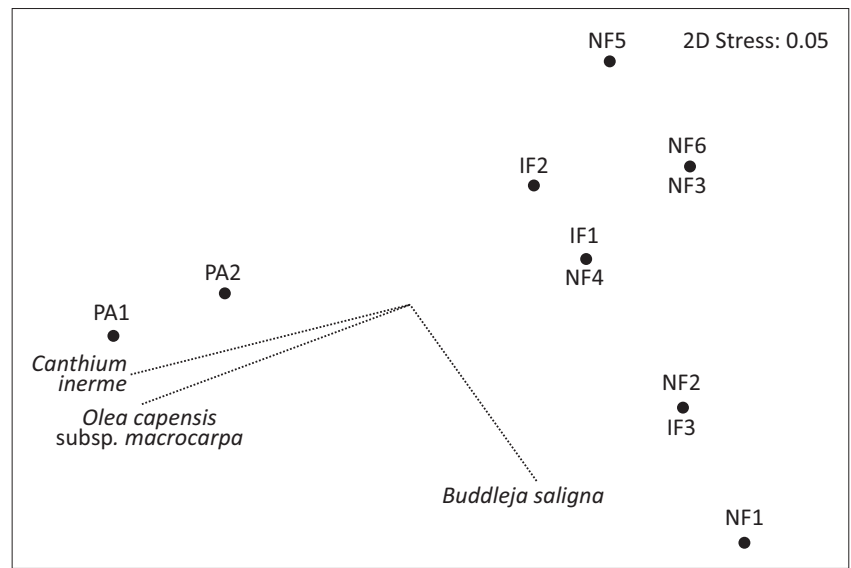

PA, protected area sites (Grootvadersbosch Nature Reserve); NF, natural fragmented patches; IF, invaded fragmented patches.

FIGURE 3: Non-metric multidimensional scaling ordination depicting the observed tree community settling activity of Charaxes xiphares occidentalis across all study sites. The indicated tree species had the strongest influence $(r>0.8)$ in structuring the observed dissimilarity in tree community settling pattern across the study area.

it was remarkable how important the proximity of a forest remnant to a larger and land-user-protected forest patch was to the number of settling and patrolling incidences. The closer a large area of protected forest at a land user was to a site (considering that the PA also acted as such a patch), the more active individuals of C. $x$. occidentalis were. However, Baguette and Van Dyck (2007) caution against extrapolating from simple Euclidean distance for describing species behaviour patterns. Still, there are some important precautionary conservation management implications for this butterfly in this unique agricultural matrix: it seems that heavily invaded fragments further away from a large intact and managed patch in the landscape (more isolated), negatively affect the behaviour of C. $x$. occidentalis. This finding should be taken into account for the conservation management priority of such spatially distributed forest remnants.

\section{Tree community settling patterns of Charaxes xiphares occidentalis in a heterogeneous landscape}

To determine whether this butterfly has a specific TCSP, we also recorded the amount of time that each individual spent settling on a tree. In a sense, settling functions as a conservation or management proxy for preference to a resource in an individual's immediate environment, as butterfly settling behaviour is strongly associated with a variety of life history 
TABLE 5: Average settling time (seconds) of Charaxes xiphares occidentalis individuals on trees at 11 sites in the Grootvadersbosch Conservancy.

\begin{tabular}{|c|c|c|c|c|c|c|c|c|c|c|c|c|c|c|c|c|c|c|c|c|c|c|}
\hline \multirow[t]{2}{*}{ Tree species } & \multicolumn{22}{|c|}{ Site category, with number of individuals observed on each tree species } \\
\hline & $\begin{array}{c}\text { PA1 } \\
{[250]^{\mathrm{a}}}\end{array}$ & Ind $d^{b}$. & $\begin{array}{c}\text { PA2 } \\
{[250]}\end{array}$ & Ind. & $\begin{array}{c}\text { NF1 } \\
{[3.8]}\end{array}$ & Ind. & $\begin{array}{c}\text { NF2 } \\
{[6.2]}\end{array}$ & Ind. & NF3 [2] & Ind. & $\begin{array}{l}\text { NF4 } \\
{[0.3]}\end{array}$ & Ind. & $\begin{array}{c}\text { NF5 } \\
{[0.2]}\end{array}$ & Ind. & $\begin{array}{l}\text { NF6 } \\
{[0.4]}\end{array}$ & Ind. & $\begin{array}{c}\text { IF1 } \\
{[0.01]}\end{array}$ & Ind. & $\begin{array}{c}\text { IF2 } \\
{[0.04]}\end{array}$ & Ind. & $\begin{array}{c}\text { IF3 } \\
{[0.15]}\end{array}$ & Ind. \\
\hline $\begin{array}{l}\text { Scutia } \\
\text { myrtina }\end{array}$ & 73.9 & 15 & 17.5 & 2 & 376.3 & 4 & 12.5 & 2 & 140.2 & 6 & 57.5 & 2 & 66 & 1 & 61.5 & 2 & 120 & 1 & 20 & 1 & 0 & - \\
\hline $\begin{array}{l}\text { Buddleja } \\
\text { saligna }\end{array}$ & 0 & - & 0 & - & 568.6 & 7 & 275.7 & 11 & 0 & - & 0 & - & 0 & - & 0 & - & 0 & - & 0 & - & 2880 & 1 \\
\hline $\begin{array}{l}\text { Psydorax } \\
\text { obovatum }\end{array}$ & 0 & - & 0 & - & 0 & - & 0 & - & 315 & 2 & 0 & - & 0 & - & 97 & 4 & 0 & - & 0 & - & 0 & - \\
\hline Ilex mitis & 66.6 & 3 & 0 & - & 0 & - & 0 & - & 0 & - & 0 & - & 0 & - & 0 & - & 0 & - & 0 & - & 0 & - \\
\hline $\begin{array}{l}\text { Canthium } \\
\text { inerme }\end{array}$ & 62.5 & 2 & 102 & 5 & 0 & - & 0 & - & 0 & - & 0 & - & 0 & - & 0 & - & 0 & - & 0 & - & 0 & - \\
\hline $\begin{array}{l}\text { Cassine } \\
\text { peragua }\end{array}$ & 9 & 1 & 0 & - & 0 & - & 0 & - & 0 & - & 0 & - & 0 & - & 0 & - & 0 & - & 0 & - & 0 & - \\
\hline $\begin{array}{l}\text { Curtisia } \\
\text { dentata }\end{array}$ & 25 & 1 & 0 & - & 0 & - & 0 & - & 0 & - & 0 & - & 0 & - & 0 & - & 0 & - & 0 & - & 0 & - \\
\hline $\begin{array}{l}\text { Scolopia } \\
\text { mundii }\end{array}$ & 5 & 1 & 0 & - & 0 & - & 0 & - & 0 & - & 0 & - & 0 & - & 0 & - & 0 & - & 0 & - & 0 & - \\
\hline $\begin{array}{l}\text { Olea } \\
\text { capensis } \\
\text { macrocarpa }\end{array}$ & 40 & 1 & 52.5 & 2 & 0 & - & 0 & - & 0 & - & 0 & - & 0 & - & 0 & - & 0 & - & 0 & - & 0 & - \\
\hline $\begin{array}{l}\text { Platylophus } \\
\text { trifoliatus }\end{array}$ & 0 & - & 360 & 1 & 0 & - & 0 & - & 0 & - & 0 & - & 0 & - & 0 & - & 0 & - & 0 & - & 0 & - \\
\hline $\begin{array}{l}\text { Podocarpus } \\
\text { latifolius }\end{array}$ & 0 & - & 300 & 1 & 0 & - & 0 & - & 0 & - & 0 & - & 0 & - & 0 & - & 0 & - & 0 & - & 0 & - \\
\hline $\begin{array}{l}\text { Searsia } \\
\text { chirindensis }\end{array}$ & 0 & - & 97.5 & 4 & 0 & - & 0 & - & 0 & - & 0 & - & 0 & - & 0 & - & 0 & - & 0 & - & 0 & - \\
\hline $\begin{array}{l}\text { Olea } \\
\text { europea } \\
\text { africana }\end{array}$ & 0 & - & 0 & - & 220 & 2 & 0 & - & 0 & - & 0 & - & 0 & - & 0 & - & 0 & - & 0 & - & 0 & - \\
\hline Searsia spp. & 0 & - & 0 & - & 3 & 1 & 0 & - & 0 & - & 0 & - & 0 & - & 0 & - & 0 & - & 0 & - & 0 & - \\
\hline $\begin{array}{l}\text { Rapanea } \\
\text { melano- } \\
\text { phloeos }\end{array}$ & 0 & - & 0 & - & 0 & - & 0 & - & 0 & - & 0 & - & 310 & 3 & 0 & - & 0 & - & 0 & - & 0 & - \\
\hline $\begin{array}{l}\text { Acacia } \\
\text { mearnsii }\end{array}$ & 0 & - & 0 & - & 0 & - & 0 & - & 0 & - & 0 & - & 0 & - & 0 & - & 0 & - & 120 & 1 & 0 & - \\
\hline
\end{tabular}

$\mathrm{IF}$, invaded fragments; NF, natural fragments; PA, protected area.

a, Patch size of intact native forest (ha) is shown in square brackets for each site.

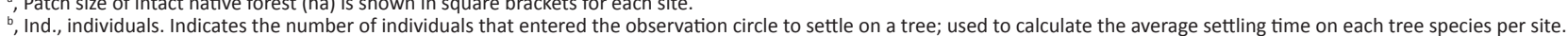

strategies such as feeding, ovipositing, basking, resting and mate location (Dennis 2004, 2010; Dennis, Shreeve \& Van Dyck 2003, 2006). Within the limits of this summer-time observation, there was a clear dissimilarity in TCSP between sites, with the two PA sites showing similar tree use activity, as did a group of NF and IF patches. In the latter group, it was the settling time of individuals on B. saligna that most strongly affected dissimilarities in the TCSP. Buddleja saligna is an endemic southern African tree species ( $2 \mathrm{~m}-7 \mathrm{~m}$ tall) and a forest margin species when associated with forest (Coates Palgrave 2005). Charaxes xiphares occidentalis feeds on the stem sap of this tree (Figure 4). Such branch-sap feeding behaviour has also been observed for two Charaxes species native to the north-eastern parts of South Africa (Forrester 2011). Indeed, Charaxes butterflies are considered frugivorous, feeding on the sap of rotting fruit, but have also been shown to feed on a variety of surface-oozing liquids, such as from tree branches (Krenn, Zulka \& Gatschnegg 2001; Molleman et al. 2005), or decaying animal matter and faeces (Molleman \& Midgley 2009). Therefore, B. saligna interaction seems to be an important habitat resource for C. $x$. occidentalis in disturbed forest fragments, especially in remnants that are now essentially isolated forest edges.

Although there is no information on the particular CharaxesBuddleja interaction in our study, this finding is consistent with Buddleja species being important as an adult butterfly

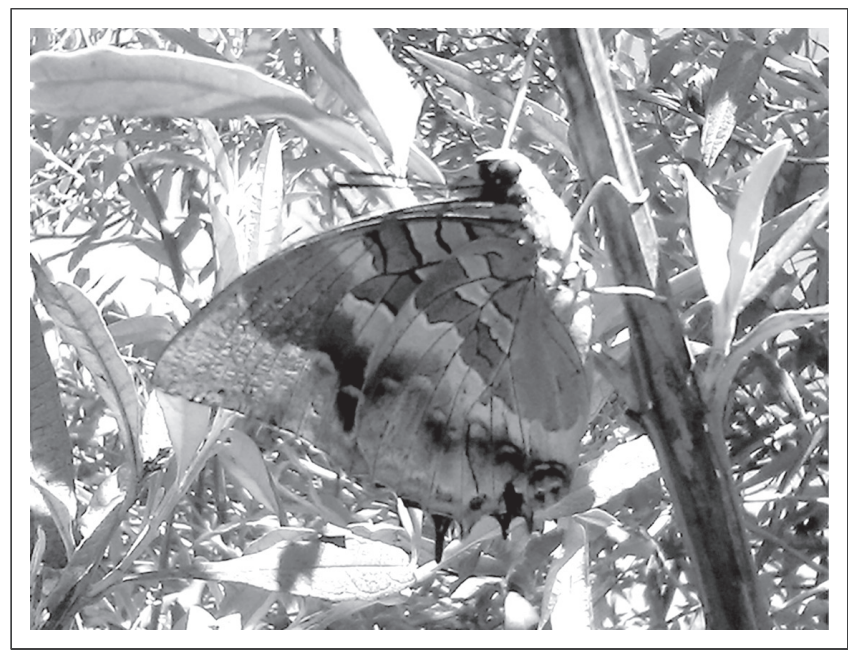

Source: Photo taken by Casparus J. Crous

FIGURE 4: A male Charaxes xiphares occidentalis individual feeding on the stem sap of a non-forest inhabiting Buddleja saligna tree.

food source (Andersson 2003; Bruner et al. 2006; Corbet 2000). For example, two Swedish Nymphalidae species showed positive antennal behaviour towards floral scent compounds of Buddleja davidii, which suggests that these compounds signal food availability (Andersson 2003). As this plant species is not indigenous to Sweden, the response perhaps emphasises the theoretical base of local adaptations by some butterflies to varying resource conditions in space and time 
(Schlaepfer et al. 2005). In comparison, a study comparing fruit-feeding butterflies between fragmented and continuous Brazilian forests highlighted how Brazilian Charaxinae species are likely able to adapt to forest fragments as they are opportunist feeders of edge-associated plant species (Uehara-Prado et al. 2007). The relevance of Buddleja spp. as a known adult butterfly food source - being edge inhabitants and the TCSP investigated here underscore that this plant must be considered in conservation planning of remnant forest fragments.

The TCSP of C. $x$. occidentalis in Southern Afrotemperate Forest in this dairy farming matrix suggests that at least two specific tree species are of importance as a habitat resource of this butterfly when active in forest fragments: S. myrtina as a larval food plant, which was the only species consistently settled upon across all sites (Table 5), and B. saligna, as an edge-specialist adult food plant. However, this butterfly did settle on a larger variety of indigenous trees in the PAs, most notably on the trees $C$. inerme and $O$. capensis, emphasising the butterfly's current need to have both intact forest and edges for two different resource behaviours in this fragmented landscape. Of course, there might be other species that could also be of significance but were not observed during this limited summer period; thus the best strategy would be simply to observe the precautionary principle and maintain as much intact forest as possible (Nyafwono et al. 2014a).

\section{Conclusion}

Native forests in South Africa are sensitive to environmental change due to high commodity production activity and, given their isolation, require conservation efforts that are focused on advanced matrix management strategies (Eeley et al. 1999). Whilst we can now confirm that the remnant patches of Southern Afrotemperate Forest across this conservancy are still suitable environments for the naturally restricted C. $x$. occidentalis, the settling patterns of this butterfly vary greatly, especially for the female individuals. This is likely because of certain habitat conditions to which they show a decrease in behavioural activity. First, dense stands of A. mearnsii may limit niche dynamics (see Holt 2009), as there was no clear evidence in this study that the butterfly uses $A$. mearnsii trees in this catchment as a resource. This emphasises the importance of the national initiative to clear this invasive tree species from the river systems in the country (Gerber et al. 2008; Hanula \& Horn 2011; Le Maitre et al. 2011). Second, there seem to be specific native tree species that are more often visited by adults of $C$. $x$. occidentalis, which also vary across this fragmented forest landscape. This is a positive response of $C$. $x$. occidentalis to different forest habitat structure. However, more information is needed regarding the specific behaviour exercised on these trees (basking or resting, as opposed to merely settling), as this would help determine the specific niche a tree provides to this butterfly. Nonetheless, this initial identification of utilised trees now allows better focus on the conservation management and rehabilitation processes for the forest patches in which C. $x$. occidentalis dwells, which should involve habitat rehabilitation through establishing native plants as well as removing invasive alien plants (Galatowitsch \& Richardson 2005; Nyafwono et al. 2014b). To achieve the current set of milestones for sustainable farming, for example the Convention on Biological Diversity's Aichi 2020 Biodiversity Targets, a resource-based butterfly conservation strategy based on behavioural ecology has great potential in the farm-scale conservation planning process globally (Crous et al. 2014; Dennis 2010; Dennis et al. 2003, 2006; Shreeve \& Dennis 2011).

\section{Acknowledgements}

This research was undertaken under a Western Cape Nature Conservation Board (CapeNature) research permit (no. 0056AA008-00023). We thank J. Groenewald for field assistance, as well as the following land users who permitted access to their estates: H. Barry, P. Groenewald and K. Moody. The Department of Science and Technology and National Research Foundation of South Africa funded this project. We also thank three anonymous reviewers for their constructive comments.

\section{Competing interests}

The authors declare that they have no financial or personal relationships that may have inappropriately influenced them in writing this article.

\section{Authors' contributions}

C.J.C. (Stellenbosch University) and M.J.S. (Stellenbosch University) conceived the study. C.J.C. was responsible for the sampling and J.S.P. (Stellenbosch University) contributed to the analysis. All three authors were involved in interpretation of the results, and all contributed to writing the manuscript.

\section{References}

Andersson, S., 2003, 'Antennal responses to floral scents in the butterflies Inachis io, Aglais urticae (Nymphalidae), and Gonepteryx rhamni (Pieridae)', Chemoecology 13, 3-20. http://dx.doi.org/10.1007/s000490300001

Baguette, M. \& Van Dyck, H., 2007, 'Landscape connectivity and animal behavior: functional grain as a key determinant for dispersal', Landscape Ecology 22, 11171129. http://dx.doi.org/10.1007/s10980-007-9108-4

Bruner, L.L., Eakes, D.J., Keever, G.J., Baier, J.W., Whitman, C.S., Knight, P.R. et al., 2006 'Butterfly feeding preferences for Buddleja selections in the landscape', Journal of Environmental Horticulture 24, 39-44.

Coates Palgrave, M., 2005, Keith Coates Palgrave: Trees of Southern Africa, Struik, Cape Town.

Corbet, S.A., 2000, 'Butterfly nectaring flowers: Butterfly morphology and flower form', Entomologia Experimentalis et Applicata 96, 289-298. http://dx.doi. org/10.1046/j.1570-7458.2000.00708.x

Crous, C.J., Samways, M.J. \& Pryke, J.S., 2014, 'Rockiness determines meso-scale conservation of butterflies in Afro-montane grassland', Journal of Insect Conservation 18, 77-83. http://dx.doi.org/10.1007/s10841-014-9616-x

Dennis, R.L.H., 2004, 'Butterfly habitats, broad-scale biotope affiliations, and structural exploitation of vegetation at finer scales: The matrix revisited', Ecological Entomology 29, 744-752. http://dx.doi.org/10.1111/j.0307-6946.2004.00646.x

Dennis, R.L.H., 2010, A resource-based habitat view for conservation: Butterflies in the British landscape, Wiley-Blackwell, Chichester.

Dennis, R.L.H., Shreeve, T.G. \& Van Dyck, H., 2003, 'Towards a functional resourcebased concept for habitat: A butterfly biology viewpoint', Oikos 102, 417-426. http://dx.doi.org/10.1034/j.1600-0579.2003.12492.x

Dennis, R.L.H., Shreeve, T.G. \& Van Dyck, H., 2006, 'Habitats and resources: the need for a resource-based definition to conserve butterflies', Biodiversity and Conservation 15, 1943-1966. http://dx.doi.org/10.1007/s10531-005-4314-3 
Dover, J. \& Settele, J., 2009, 'The influences of landscape structure on butterfly distribution and movement: A review', Journal of Insect Conservation 13, 3-27. http://dx.doi.org/10.1007/s10841-008-9135-8

Dye, P. \& Jarmain, C., 2004, 'Water use by black wattle (Acacia mearnsii): Implications for the link between removal of invading trees and catchment streamflow response', South African Journal of Science 100, 40-44.

Edge, D.A., 2005, 'Butterfly conservation in the southern Cape', Metamorphosis 16 $28-46$.

Eeley, H.A.C., Lawes, M.J. \& Piper, S.E., 1999, 'The influence of climate change on the distribution of indigenous forest in KwaZulu-Natal, South Africa', Journal of Biogeography 26, 595-617. http://dx.doi.org/10.1046/j.1365-2699.1999.00307.x

Enright, W.D., 2000, 'The effect of terrestrial invasive alien plants on water scarcity in South Africa', Physics and Chemistry of the Earth, Part B: Hydrology, Oceans and Atmosphere 25, 237-242. http://dx.doi.org/10.1016/S1464-1909(00)00010-1

Ersts, P.J., n.d., Geographic Distance Matrix Generator (v 1.2.3), computer software, viewed 16 April 2014, from http://biodiversityinformatics.amnh.org/open_source/gdmg (American Museum of Natural History, Center for Biodiversity and Conservation).

Fargione, J.E. \& Tilman, D., 2005, 'Diversity decreases invasion via both sampling and complementarity effects', Ecology Letters 8, 604-611. http://dx.doi.org/10.1111/ j.1461-0248.2005.00753.x

Fermon, H., Waltert, M., Larsen, T.B., Dall'Asta, U. \& Mühlenberg, M., 2000, 'Effects of forest management on diversity and abundance of fruit-feeding nymphalid butterflies in south-eastern Côte d'Ivoire', Journal of Insect Conservation 4, 173-189. http://dx.doi.org/10.1023/A:1009638808635

Florens, F.B.V., Mauremootoo, J.R., Fowler, S.V., Winder, L. \& Baider, C., 2010, 'Recovery of indigenous butterfly community following control of invasive alien plants in tropical island's wet forests', Biodiversity and Conservation 19, 3835-3848. http:// dx.doi.org/10.1007/s10531-010-9930-x

Forrester, W.S., 2011, 'Fruit-feeding butterfly assemblages at Dlinza and Entumeni Nature Reserves, KwaZulu-Natal: a quantitative biodiversity study', MSc dissertation, School of Environmental Science, North-West University.

Francesconi, W., Nair, P.K.R., Levey, D.J., Daniels, J. \& Cullen, L., 2013, 'Butterfly distribution in fragmented landscapes containing agroforestry practices in
southeastern Brazil', Agroforestry Systems 87, 1321-1338. http://dx.doi. southeastern Brazil', Agroforestry
org/10.1007/s10457-013-9640-y

Galatowitsch, S. \& Richardson, D.M., 2005, 'Riparian scrub recovery after clearing of invasive alien trees in headwater streams of the Western Cape, South Africa', Biological Conservation 122, 509-521. http://dx.doi.org/10.1016/j. Africa', Biological
biocon.2004.09.008

Gerber, E., Krebs, C., Murrell, C., Moretti, M., Rocklin, R. \& Schaffner, U., 2008, 'Exotic invasive knotweeds (Fallopia spp.) negatively affect native plant and invertebrate assemblages in European riparian habitats', Biological Conservation 141 assemblages in European riparian habitats', Biological

Ghazoul, J., 2004, 'Alien abduction: Disruption of native plant-pollinator interactions by invasive species', Biotropica 36, 156-164. http://dx.doi. org/10.1111/j.1744-7429.2004.tb00308.x

Graves, S.D. \& Shapiro, A.M., 2003, 'Exotics as host plants of the California butterfly fauna', Biological Conservation 110, 413-433. http://dx.doi.org/10.1016/S00063207(02)00233-1

Hamer, K.C., Hill, J.K., Benedick, S., Mustaffa, N., Sherratt, T.N., Maryati, M. et al., 2003, 'Ecology of butterflies in natural and selectively logged forests of northern Borneo: the importance of habitat heterogeneity', Journal of Applied Ecology 40 150-162. http://dx.doi.org/10.1046/j.1365-2664.2003.00783.x

Hanula, J.L. \& Horn, S., 2011, 'Removing an exotic shrub from riparian forests increases butterfly abundance and diversity', Forest Ecology and Management 262, 674-680. http://dx.doi.org/10.1016/j.foreco.2011.04.040

Holt, R.D., 2009, 'Bringing the Hutchinsonian Niche into the $21^{\text {st }}$ Century: Ecological and evolutionary perspectives', Proceedings of the National Academy of Sciences USA 106, 19659-19665. PMID: 19903876, http://dx.doi.org/10.1073/ pnas.0905137106

Hood, W.G. \& Naiman, R.J., 2000, 'Vulnerability of riparian zones to invasion by exotic vascular plants', Plant Ecology 148, 105-114. http://dx.doi. by exotic vascular plants',
org/10.1023/A:1009800327334

Koh, L.P. \& Sodhi, N.S., 2004, 'Importance of reserves, fragments, and parks for butterfly conservation in a tropical urban landscape', Ecological Applications 14 1695-1708. http://dx.doi.org/10.1890/03-5269

Krenn, H.W., Zulka, K.P. \& Gatschnegg, T., 2001, 'Proboscis morphology and food preferences in nymphalid butterflies (Lepidoptera: Nymphalidae)', Journal of Zoology 254, 17-26. http://dx.doi.org/10.1017/S0952836901000528

Lawrence, J.M. \& Samways, M.J., 2002, 'Influence of hilltop vegetation type on an African butterfly assemblage and its conservation', Biodiversity and Conservation 11, 1163-1171. http://dx.doi.org/10.1023/A:1016017114473
Le Maitre, D.C., Gaertner, M., Marchante, E., Ens, E.-J., Holmes, P.M., Pauchard, A. et al., 2011, 'Impacts of invasive Australian acacias: Implications for management and restoration', Diversity and Distributions 17, 1015-1029. http://dx.doi. and restoration', Diversity and Distribu

Le Maitre, D.C., Van Wilgen, B.W., Gelderblom, C.M., Bailey, C., Chapman, R.A. \& Nel, J.A., 2002, 'Invasive alien trees and water resources in South Africa: Case studies of the costs and benefits of management', Forest Ecology and Management 160, 143-159. http://dx.doi.org/10.1016/S0378-1127(01)00474-1

Lu, S.-S. \& Samways, M.J., 2002, 'Conservation management recommendations for the Karkloof blue butterfly, Orachrysops ariadne (Lepidoptera: Lycaenidae)', African Entomology 10, 149-159.

McKinney, M.L. \& Lockwood, J.L., 1999, 'Biotic homogenization: A few winners replacing many losers in the next mass extinction', Trends in Ecology and Evolution 14, 450-453. http://dx.doi.org/10.1016/S0169-5347(99)01679-1

Molleman, F., Krenn, H.W., Van Alphen, M.E., Brakefield, P.M., Devries, P.J. \& Zwaan, B.J., 2005, 'Food intake of fruit-feeding butterflies: Evidence for adaptive variation in proboscis morphology', Biological Journal of the Linnean Society 86, 333-343. http://dx.doi.org/10.1111/j.1095-8312.2005.00533.x

Molleman, F. \& Midgley, J.J., 2009, ' $\delta{ }^{15} \mathrm{~N}$ analyses of butterfly wings and bodies suggest minimal nitrogen absorption in carrion and dung puddling butterflies (Lepidoptera: Nymphalidae)', Journal of Research on the Lepidoptera 41, 14-16.

Mucina, L. \& Rutherford, M.C., 2006, The Vegetation of South Africa, Lesotho and Swaziland, South African National Biodiversity Institute, Pretoria.

Nel, J.L., Roux, J.L., Maree, G., Kleynhans, C.J., Moolman, J., Reyers, B. et al., 2007, 'Rivers in peril inside and outside protected areas: A systematic approach to conservation assessment of river ecosystems', Diversity and Distributions 13 , 341-352. http://dx.doi.org/10.1111/j.1472-4642.2007.00308.x

New, T.R., 1991, Butterfly conservation, Oxford University Press, Melbourne.

Nyafwono, M., Valtonen, A., Nyeko, P. \& Roininen, H., 2014a, 'Butterfly community composition across a successional gradient in a human-disturbed Afro-tropical rain forest', Biotropica 46, 210-218. http://dx.doi.org/10.1111/btp.12085

Nyafwono, M., Valtonen, A., Nyeko, P. \& Roininen, H., 2014b, 'Fruit-feeding butterfly communities as indicators of forest restoration in an Afro-tropical rainforest', Biological Conservation 174, 75-83. http://dx.doi.org/10.1016/j.biocon.2014.03.022

Ricketts, T.H., 2001, 'The matrix matters: Effective isolation in fragmented landscapes', American Naturalist 158, 87-99.

Rutowski, R.L., 1991, 'The evolution of mate-locating behavior in butterflies', American Naturalist 138, 1121-1139.

Schlaepfer, M.A., Sherman, P.W., Blossey, B. \& Runge, M.C., 2005, 'Introduced species as evolutionary traps', Ecology Letters 8, 241-246. http://dx.doi.org/10.1111/ j.1461-0248.2005.00730.x

Shackleton, C.M., Shackleton, S.E., Buiten, E. \& Bird, N., 2007, 'The importance of dry woodlands and forests in rural livelihoods and poverty alleviation in South
Africa', Forest Policy and Economics 9, 558-577. http://dx.doi.org/10.1016/j. Africa', Forest Policy
forpol.2006.03.004

Shreeve, T.G., 1984, 'Habitat selection, mate location, and microclimatic constraints on the activity of the Speckled Wood butterfly Pararge aegeria', Oikos 42, 371-377.

Shreeve, T.G. \& Dennis, R.L.H., 2011, 'Landscape scale conservation: Resources, behaviour, the matrix and opportunity', Journal of Insect Conservation 15, 179-188. http://dx.doi.org/10.1007/s10841-010-9336-9

Sutherland, W.J., 1998, 'The importance of behavioural studies in conservation biology', Animal Behaviour 56, 801-809. http://dx.doi.org/10.1006/anbe.1998.0896

Ter Braak, C.J.F., 1995, 'Ordination', in R.H.G. Jongman, C.J.F. ter Braak \& O.F.R. van Tongeren (eds.), Data analysis in community and landscape ecology, pp. 91-173, Cambridge University Press, Cambridge.

Thomas, J.A., 1984, 'The behaviour and habitat requirements of Maculinea nausithous (the Dusky Blue Butterfly) and M. teleius (the Scarce Large Blue) in nausithous (the Dusky Blue Butterfly) and M. teleius (the Scarce Large Blue) in
France', Biological Conservation 28, 325-347. http://dx.doi.org/10.1016/0006France', Biological
3207(84)90040-5

Turlure, C., Baguette, M., Stevens, V.M. \& Maes, D., 2011, 'Species- and sex-specific adjustments of movement behavior to landscape heterogeneity in butterflies', Behavioral Ecology 22, 967-975. http://dx.doi.org/10.1093/beheco/arr077

Uehara-Prado, M., Brown, K.S. \& Freitas, A.V.L., 2007, 'Species richness, composition and abundance of fruit-feeding butterflies in the Brazilian Atlantic Forest: Comparison between a fragmented and a continuous landscape', Global Ecology and Biogeography 16, 43-54. http://dx.doi.org/10.1111/j.1466-8238.2006.00267.x

Valtonen, A., Jantunen, J. \& Saarinen, K., 2006, 'Flora and Lepidoptera fauna adversely affected by invasive Lupinus polyphyllus along road verges', Biological Conservation 133, 389-396. http://dx.doi.org/10.1016/j.biocon.2006.06.015

Woodhall, S., 2005, Field guide to butterflies of South Africa, Struik Nature, Cape Town. 